\title{
Candidate genes in quantitative trait loci associated with absolute and relative kidney weight in rats with Inherited Stress Induced Arterial Hypertension
}

\author{
Olga E Redina 1*, Svetlana E Smolenskaya', Leonid O Klimov', Arcady L Markel ${ }^{1,2}$
}

From IX International Conference on the Bioinformatics of Genome Regulation and StructurelSystems Biology (BGRS\SB-2014)

Novosibirsk, Russia. 23-28 June 2014

\begin{abstract}
Background: The kidney mass is significantly increased in hypertensive ISIAH rats with Inherited Stress Induced Arterial Hypertension as compared with normotensive WAG rats. The QTL/microarray approach was carried out to determine the positional candidate genes in the QTL for absolute and relative kidney weight.

Results: Several known and predicted genes differentially expressed in ISIAH and WAG kidney were mapped to genetic loci associated with the absolute and relative kidney weight in 6-month old F2 hybrid (ISIAHxWAG) males. The knowledge-driven filtering of the list of candidates helped to suggest several positional candidate genes, which may be related to the structural and mass changes in hypertensive ISIAH kidney.

In the current study, we showed that all loci found for absolute and relative kidney weight didn't overlap with significant or suggestive loci for arterial blood pressure level. So, the genes differentially expressed in ISIAH and WAG kidneys and located in these QTL regions associated with absolute and relative kidney weight shouldn't substantially influence the BP level in the 6 month-old ISIAH rats. However, in some cases, small effects may be suggested.
\end{abstract}

Conclusions: The further experimental validation of causative genes and detection of polymorphisms will provide opportunities to advance our understanding of the underlying nature of structural and mass changes in hypertensive ISIAH kidney.

\section{Background}

Renal function plays a major role in long-term control of arterial blood pressure and sodium balance [1]. Kidney as a target organ in hypertension is widely investigated. Differences in the kidney size have been observed between most rat models of hypertension and their respective normotensive controls [2]. The alterations in kidney size may occur as a consequence of pathophysiological processes underlying the hypertension development. Several studies

\footnotetext{
* Correspondence: oredina@ngs.ru

'Institute of Cytology and Genetics, Siberian Branch of Russian Academy of Sciences, Novosibirsk, 630090 Russia

Full list of author information is available at the end of the article
}

were conducted in order to find the genetic determinants for hypertensive dependent relative kidney weight changes and several genetic loci associated with this trait were found $[2,3]$. However little is known about particular genes participating in the trait manifestation.

The use of experimental animal models provides valuable information to elucidate the nature of polygenic traits [4]. The ISIAH (Inherited Stress-Induced Arterial Hypertension) rat strain was developed to study the mechanisms of the stress-induced hypertension and its complications [5]. The ISIAH rats show a number of characteristic features of hypertensive state: the elevated systolic arterial blood pressure (SABP) at basal condition, 
a dramatic increase in SABP when restrained, hypertrophy of the heart left ventricle, increase in the wall thickness of the small arteries, and changes in the ECG pattern [6]. In addition, ISIAH rats have significantly increased kidney mass as compared to normotensive controls [7].

Earlier we used quantitative trait loci (QTL) approach, which helps to map the genomic regions associated with the phenotypic variation of quantitative physiological traits, and we described several QTL for absolute and relative kidney weight in 6 month old $\mathrm{F}_{2}($ ISIAH $\times$ WAG) hybrid male rats [8]. Our results suggested that absolute and relative kidney weights are complex phenotypes resulting from a large number of factors, each exhibiting a small effect QTL for hypertension.

The combined use of QTL mapping and subsequent microarray profiling of nonrecombinant parental strains is recognized as a powerful tool to identify the genes underlying QTL [9] and to reduce the number of candidate genes in the QTL regions $[10,11]$.

Earlier we described the results of the comparative analysis of gene expression profiling which revealed differentially expressed genes in kidney of hypertensive ISIAH and normotensive WAG rats. The functional annotation of the genes differentially expressed in ISIAH and WAG kidney helped to suggest the genetic determinants related to blood pressure control in ISIAH rats. The analysis showed that many genes are working in stress-related mode in hypertensive kidney and the alterations in gene expression are likely related to both pathophysiological and compensatory mechanisms [12].

The present work was carried out to determine the differentially expressed genes present in QTL for absolute and relative kidney weight in 6 month old $\mathrm{F}_{2}(\mathrm{ISIAH} \times$ WAG) hybrid male rats and related to the mechanisms defining the differences in hypertensive and normotensive kidney weight.

In the current study, several known and predicted genes differentially expressed in ISIAH and WAG kidney were mapped to genetic loci associated with the absolute and relative kidney weight in 6-month old $\mathrm{F}_{2}$ hybrid (ISIAHxWAG) males. The knowledge-driven filtering of the list of candidates helped to suggest several positional candidate genes, which may be related to the structural and mass changes in hypertensive ISIAH kidney. Besides, we showed that loci for absolute and relative kidney weight didn't overlap with significant or suggestive loci for arterial blood pressure level. The role of loci with small effects is discussed.

\section{Methods}

\section{Animals}

The hypertensive ISIAH (Inherited Stress Induced Arterial Hypertension) and normotensive WAG (Wistar
Albino Glaxo) rats bred in the Laboratory of Experimental Animals at the Institute of Cytology and Genetics (Novosibirsk, Russia) were used. All rats were maintained in the standard conditions with free access to food and water. All animal experiments were approved by the Institute's Animal Care and Use Committee.

The description of animals used in QTL analysis was given earlier [7]. QTL analysis for absolute and relative kidney weight was performed using 6 -month old $\mathrm{F}_{2}$ hybrid males $(n=126)$ derived from a cross of ISIAH and WAG rats. The genome scan was carried out with 149 polymorphic microsatellite markers (141 markers were for autosomes and 8 markers were for chromosome $\mathrm{X})$. The list of markers and the genomic coverage data are available on the site of Institute of Cytology and Genetics SB RAS http://icg.nsc.ru/isiah/en/category/qtl/. The relative kidney weight was expressed as the ratio of organ weight to the body weight (g/100 g b.w.).

The 6-month old ISIAH $(\mathrm{n}=3)$, and WAG $(\mathrm{n}=3)$ males were used in microarray experiments. Their SABP was $173.67 \pm 1.86 \mathrm{mmHg}$ in ISIAH and $124.67 \pm 2.67$ $\mathrm{mmHg}$ in WAG males. The SABP was measured indirectly by the tail-cuff method. The blood pressure level was determined under short-term ether anesthesia to exclude the effect of psychological stress induced by the measuring procedure. Renal cortex and renal medulla were analyzed separately. The kidney of the decapitated rats was immediately removed and sectioned to get the samples of renal cortex and renal medulla. Samples (50 mg) were homogenized in $1 \mathrm{ml}$ of TRIzol (Invitrogen Life Technologies, USA) in glass homogenizers, removed to $1.5-\mathrm{ml}$ Eppendorf tubes and stored at $-70^{\circ} \mathrm{C}$ until RNA isolation.

The details of QTL analysis were described earlier $[8,13]$. Genomic DNA was prepared from liver by the conventional method using Proteinase $\mathrm{K}$ and phenolchloroform extraction. Isolated genomic DNA was precipitated and dissolved in deionized water. The http:// www.ensembl.org/Rattus_norvegicus database was used to define the relative positions of the markers along chromosomes given in Megabases (Mb). Genotyping: 50-100 ng of genomic DNA was amplified by PCR in reaction buffer containing $2 \mu \mathrm{mol}$ of each primer, $200 \mu \mathrm{mol}$ of each dNTP, $1.5 \mathrm{mmol} \mathrm{MgCl}_{2}$ and $0.2 \mathrm{U}$ of Taq DNA Polymerase (Medigen, Russia). The PCR reactions were performed following the protocol: initial denaturation at $95^{\circ} \mathrm{C}$ for 3 minutes, followed by 38 cycles of denaturation at $94^{\circ} \mathrm{C}$ for 20 seconds, annealing for 15 seconds at a temperature specific to each pair of primers and elongation at $72^{\circ} \mathrm{C}$ for 20 seconds. Cycles were followed by a final extension step at $72^{\circ} \mathrm{C}$ for 5 minutes. The time of elongation was not varied because all the amplified fragments were shorter than 300 nucleotides. The product of each tube was analyzed 
by electrophoresis in 6-8\% polyacrylamide gel in TBE buffer at $10 \mathrm{~V} / \mathrm{cm}$. The separated fragments were visualized by staining with ethidium bromide and analyzed on gel-imager Biometra (Germany).

\section{Linkage and statistical analysis}

The data for relative kidney weight were transformed using natural logarithm to reduce skewness and kurtosis in the distribution. Linkage analysis was done using the MAPMAKER/EXP 3.0 and MAPMAKER/QTL 1.1 programs kindly provided by Dr. Eric Lander (Whitehead Institute, Cambridge, MA) [14]. The chromosome $\mathrm{X}$ was analyzed as backcross group. The QTL boundaries were determined in the respective one LOD confidence interval. Position of markers was given in megabases $(\mathrm{Mb})$ according to RGSC Genome Assembly v 5.0.

The QTL Cartographer Version 1.17, JZmapqtl http:// statgen.ncsu.edu $[15,16]$ was used to assess genomewide and chromosome-wise empirical significant threshold values for QTLs. Permutation test was done using 1000 permutations of the original data [17]. The LOD scores exceeding $5 \%$ experiment wise threshold value were taken as significant evidence of linkage [18]. LOD scores exceeding $5 \%$ chromosome-wise threshold value were considered as suggestive linkage.

\section{Microarray experiments}

The collected samples were sent to JSC Genoanalytica (Moscow, Russia), where total RNA was extracted and processed. Three samples from ISIAH kidney and three samples from WAG kidney were run as experimental replicates. Four hundred nanograms of total RNA was used for complementary RNA in vitro transcription, followed by a T7 RNA polymerase-based linear amplification and labeling with the TotalPrep RNA Labeling Kit using Biotinylated-UTP (Ambion, Austin, TX). The signal was developed by staining with Cy3-streptavidin. The hybridization was performed on Illumina RatRef-12 Expression BeadChip microarray platform containing 22,524 probes for a total of 22, 228 rat genes selected primarily from the National Center for Biotechnology Information RefSeq database (Release 16; Illumina, San Diego, CA, USA). Hybridization, washing and staining were carried out according to the Illumina Gene Expression Direct Hybridization Manual. The BeadChip was scanned on a highresolution Illumina BeadArray reader.

\section{Microarray data extraction, normalization, and analyses}

The primary statistical analysis of the hybridization results was performed by JSC Genoanalytica (Moscow, Russia). The Illumina GenomeStudio software was used to extract fluorescence intensities and normalize the expression data. Data acquisition and analysis were done using gene expression module and rank invariant normalization. After normalization, genes were filtered by their 'detection' p-value, which had to be less then 0.01 (significantly detected), in both samples. Subsequently, the differentially expressed genes were identified using the Illumina Custom error model, which provides an expression difference score (Diff-Score) taking into account background noise and sample variability. Genes were considered significantly changed at a |Differential Score| of more than 20, which was equivalent to a p-value of less than 0.01 . Fold changes were calculated as ratio of gene expression value in ISIAH to gene expression value in WAG. The lists of genes differentially expressed in kidney of hypertensive ISIAH and normotensive WAG rats are available on the site of Institute of Cytology and Genetics SB RAS http://icg.nsc.ru/ isiah/en/. Heatmaps were constructed from normalized signals using gplots package for R statistical software http://cran.r-project.org/web/packages/gplots/index.html.

\section{Results and discussion}

Many different reasons may cause the increase of the kidney weight. It may be modified by hypertrophy and/ or hyperplasia of the kidney tissues. Each of these processes may be under common and partly separate control and may be triggered also by some common and specific stimuli [19].

The significant positive correlation was shown between kidney weight and glomerular number and size [20]. Comparative electron microscopic study of glomerular apparatus in 6-month old ISIAH and Wistar rats showed hypertrophy of renal corpuscles in hypertensive kidney, accompanied by multiple structural changes such as capillary narrowing or dilation, endothelial flattening, podocyte hypertrophy and flattening of their cytopodia, thickening of basal lamina, mesangial volume expansion and increase in the number of intercapillary processes of mesangial cells [21]. Besides, the renal medullary interstitial cells of ISIAH kidneys were characterized by higher numerical density and were enlarged with a higher volume share of their secretory granules [22]. Complex of these signs suggested a disturbance of glomerular capillary blood circulation and a functional podocyte stress, compensating the microcirculatory disturbances. Changes in basal membranes and mesangium are indicative of not only increase in filtration barrier functional load, but also of initial stages of glomerular [21] and renomedullar sclerosis [22].

The QTL analysis revealed 6 suggestive loci for kidney weight on chromosomes 4, 6, 10, 15, 17, and X. One significant locus on Chr.7 and three suggestive loci on Chr.2, 3, and 6 were found for relative kidney weight. The description of all these loci was done earlier [8].

Comparative analysis of gene expression profiling in kidney of hypertensive ISIAH and normotensive WAG rats revealed 126 differentially expressed genes in renal 
cortex and 65 differentially expressed genes in renal medulla [12]. The hierarchical clustering and heatmaps illustrating each individual's expression pattern in genes differentially expressed $(p<0,01)$ in kidney of hypertensive ISIAH and normotensive WAG rats are shown in Figures 1 and 2. In the present work we determined several differentially expressed genes (Table 1 Figures 3, 4, 5, 6, 7, 8, 9) mapped to genetic loci

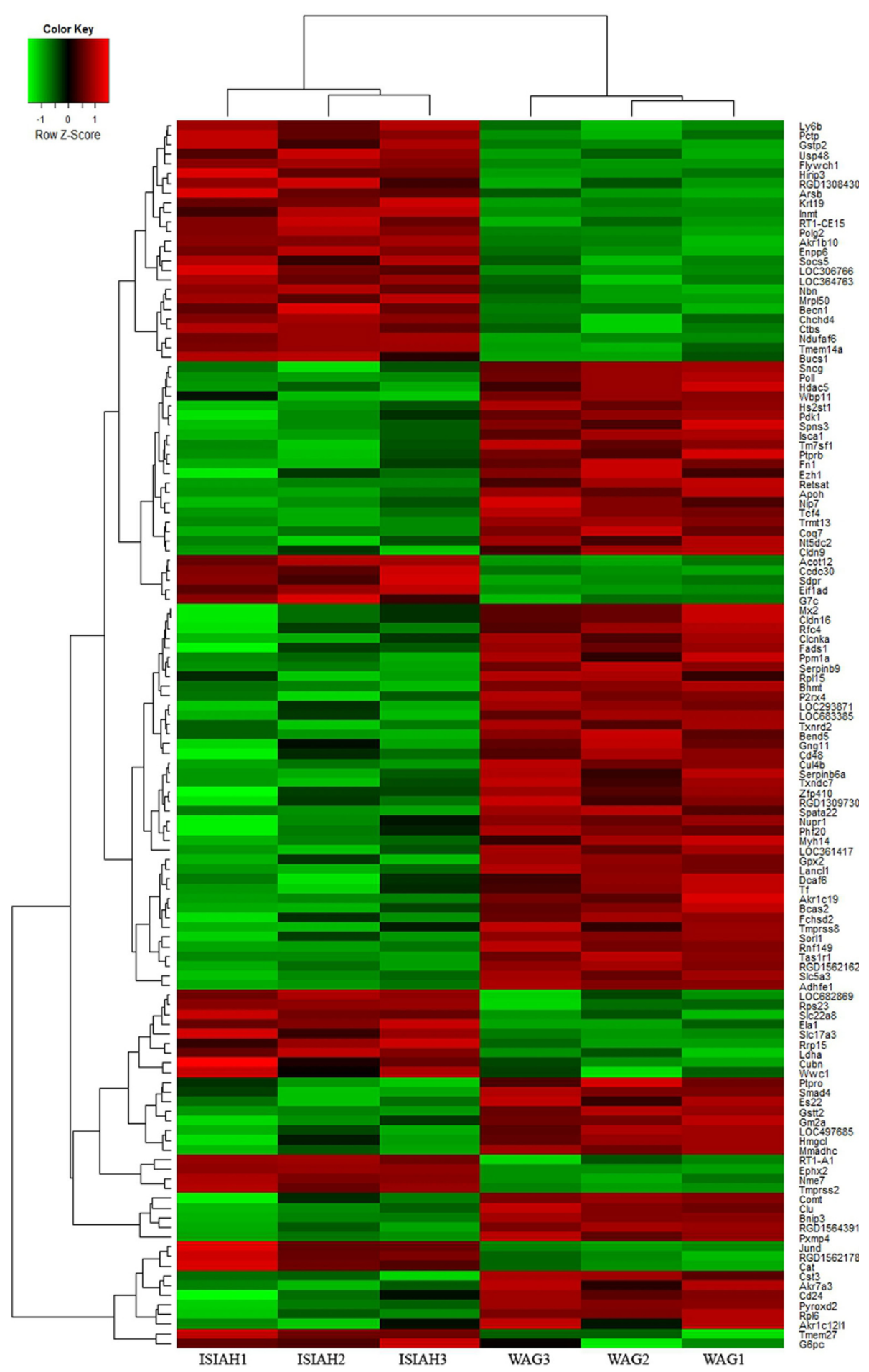

Figure 1 Hierarchical clustering of the genes differentially expressed in renal cortex of hypertensive ISIAH and normotensive WAG rats Normalised gene expression is indicated by the row Z-score where red represents upregulated genes and green represents downregulated genes. 


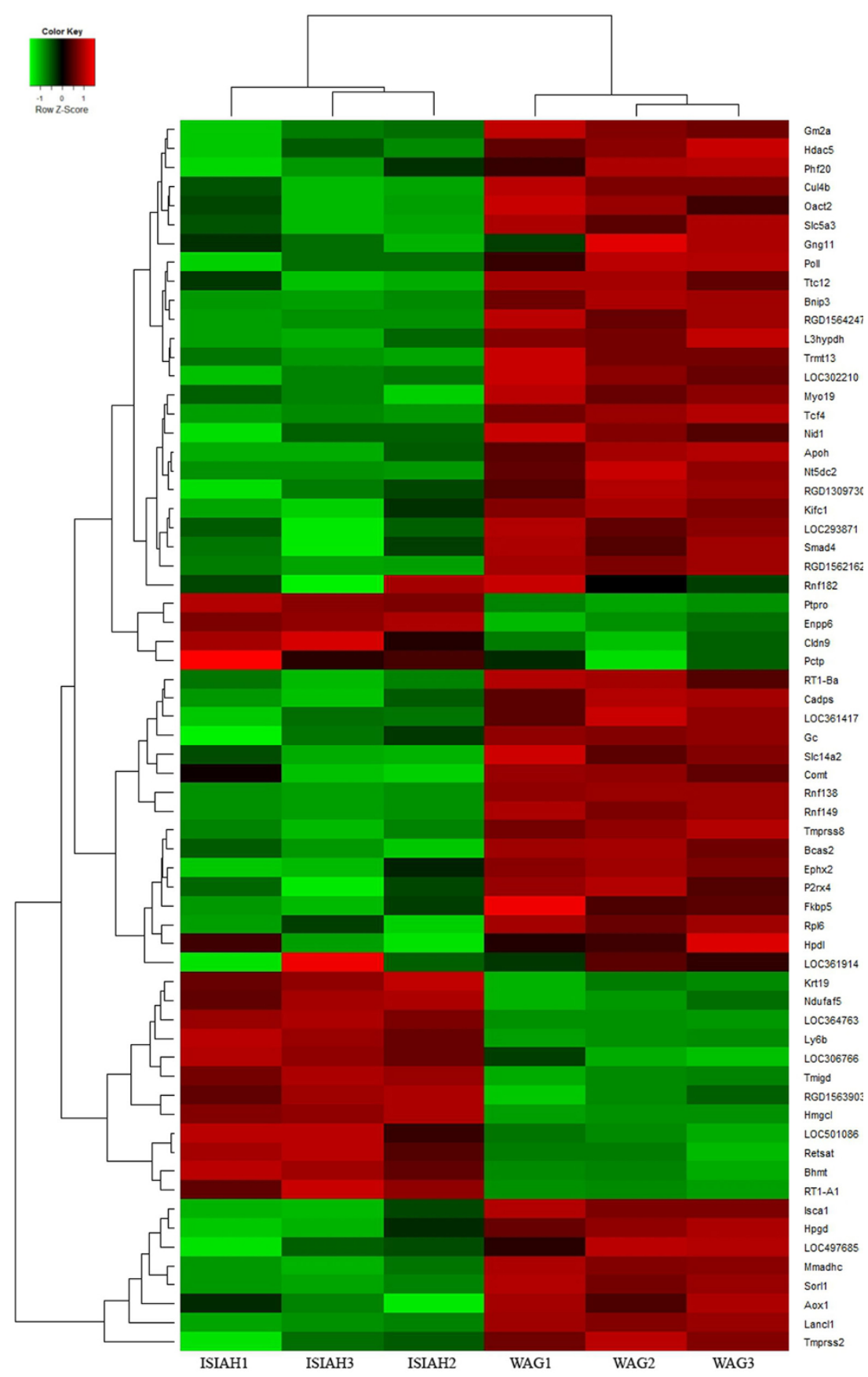

Figure 2 Hierarchical clustering of the genes differentially expressed in renal medulla of hypertensive ISIAH and normotensive WAG rats. Normalised gene expression is indicated by the row Z-score where red represents upregulated genes and green represents downregulated genes.

associated with the absolute and relative kidney weight described earlier for 6 -month old $\mathrm{F}_{2}(\mathrm{ISIAH} \times \mathrm{WAG})$ hybrid male rats [8]. It is considered that the determination of differentially expressed genes between selected lines of animals, and their localization within QTLs for the selected phenotype, dramatically increases the probability of identifying genes that contribute to that phenotype through differential expression $[10,11,23]$. It is understandable that both real target genes and genes located in loci just by chance could be found among these genes. The further discussion will help to discriminate between the differentially expressed genes located 
Table 1 Genes differentially expressed in ISIAH and WAG kidney and localized in QTL for absolute and relative kidney weight in 6-month old $F_{2}$ (ISIAH $\times$ WAG) males

\begin{tabular}{|c|c|c|c|c|c|c|c|}
\hline \multicolumn{3}{|c|}{ QTL } & \multicolumn{5}{|c|}{ Genes differentially expressed in ISIAH and WAG kidney ${ }^{\Delta}$} \\
\hline Chr. & $\begin{array}{l}\text { Peak } \\
\text { marker } \\
(\mathrm{Mb})\end{array}$ & $\begin{array}{l}\text { Confidence } \\
\text { interval, * } \\
\text { Mb }\end{array}$ & $\begin{array}{c}\text { Ratio } \\
\text { ISIAH/ WAG }\end{array}$ & Acc.\# & Symbol & $\mathrm{Mb}$ & Definition \\
\hline \multicolumn{8}{|c|}{ kidney_weight } \\
\hline 4 & $\begin{array}{l}\text { D4Rat68 } \\
(233.3)\end{array}$ & $204-242$ & $\begin{array}{c}0.37 \\
0.56(p<0.05) \\
\mathbf{0 . 3 6}\end{array}$ & $\begin{array}{l}\text { NM_001009661.1 } \\
\text { NM_017336.1 } \\
\text { NM_017336.1 }\end{array}$ & $\begin{array}{l}\text { Wbp11 } \\
\text { Ptpro } \\
\text { Ptpro }\end{array}$ & $\begin{array}{l}234.4 \\
235.5 \\
\mathbf{2 3 5 . 5}\end{array}$ & $\begin{array}{l}\text { WW domain binding protein } 11 \\
\text { Protein tyrosine phosphatase, receptor type, } 0 \\
\text { Protein tyrosine phosphatase, receptor type, } 0\end{array}$ \\
\hline 6 & $\begin{array}{l}\text { D6Rat143 } \\
(48.1)\end{array}$ & $42-62$ & $\begin{array}{l}0.56 \\
\mathbf{0 . 3 8}\end{array}$ & $\begin{array}{l}\text { XM_576132.1 } \\
\text { XM_001074910.1 }\end{array}$ & $\begin{array}{l}\text { Txndc7 } \\
\text { Oact2 }\end{array}$ & $\begin{array}{l}52.3 \\
60.9\end{array}$ & $\begin{array}{l}\text { Thioredoxin domain containing } 7 \\
\text { O-acyltransferase (membrane bound) domain } \\
\text { containing } 2\end{array}$ \\
\hline 10 & $\begin{array}{l}\text { D10Rat43 } \\
(22.3)\end{array}$ & $10-58$ & $\begin{array}{l}1.69 \\
0.42 \\
\mathbf{0 . 3 8}\end{array}$ & $\begin{array}{l}\text { XM_220308.4 } \\
\text { NM_172335.2 } \\
\text { NM_172335.2 }\end{array}$ & $\begin{array}{l}\text { Wwc1 } \\
\text { Gm2a } \\
\text { Gm2a }\end{array}$ & $\begin{array}{l}20.5 \\
40.3 \\
\mathbf{4 0 . 3}\end{array}$ & $\begin{array}{l}\text { WW and C2 domain containing } 1 \\
\text { GM2 ganglioside activator } \\
\text { GM2 ganglioside activator }\end{array}$ \\
\hline 15 & $\begin{array}{l}\text { D15Rat80 } \\
(30.3)\end{array}$ & $18-50$ & $\begin{array}{l}\mathbf{0 . 2 8} \\
1.66 \\
\end{array}$ & $\begin{array}{l}\text { NM_013219.1 } \\
\text { XM_001054512.1 }\end{array}$ & $\begin{array}{c}\text { Cadps } \\
\text { RGD1308430 } \\
\end{array}$ & $\begin{array}{l}19.3 \\
37.2\end{array}$ & $\begin{array}{l}\text { Ca++-dependent secretion activator } \\
\text { Similar to } 1700123 \text { O20Rik protein }\end{array}$ \\
\hline 17 & $\begin{array}{l}\text { D17Rat107 } \\
(11.8)\end{array}$ & $0-24$ & $\begin{array}{l}1.84 \\
0.51 \\
\mathbf{0 . 3 5} \\
0.08 \\
6.54 \\
\mathbf{5 . 0 6} \\
\end{array}$ & $\begin{array}{l}\text { XM_001061265.1 } \\
\text { NM_181626.3 } \\
\text { NM_181626.3 } \\
\text { XM_346945.2 } \\
\text { NM_001014007.1 } \\
\text { NM_001014007.1 }\end{array}$ & $\begin{array}{l}\text { LOC682869 } \\
\text { Isca1 } \\
\text { Isca1 } \\
\text { RGD1564391 } \\
\text { LOC306766 } \\
\text { LOC306766 }\end{array}$ & $\begin{array}{r}5.1 \\
7.5 \\
\mathbf{7 . 5} \\
7.8 \\
12.7 \\
\mathbf{1 2 . 7} \\
\end{array}$ & $\begin{array}{l}\text { similar to Golgi phosphoprotein } 2 \text { (Golgi membrane } \\
\text { protein GP73), transcript variant } 2 \\
\text { Iron-sulfur cluster assembly } 1 \text { homolog (S. cerevisiae) } \\
\text { Iron-sulfur cluster assembly } 1 \text { homolog (S. cerevisiae) } \\
\text { RGD1564391 (predicted) } \\
\text { Hypothetical LOC306766 } \\
\text { Hypothetical LOC306766 }\end{array}$ \\
\hline \multicolumn{8}{|c|}{ In_relative_kidney_weight } \\
\hline 3 & $\begin{array}{l}\text { D3Rat56- } \\
\text { D3Rat130 } \\
(2.6-55.2)\end{array}$ & $0-62$ & $\begin{array}{l}0.37 \\
\mathbf{0 . 1 1}\end{array}$ & $\begin{array}{l}\text { NM_001004280.1 } \\
\text { NM_001004280.1 }\end{array}$ & $\begin{array}{l}\text { Mmadhc } \\
\text { Mmadhc }\end{array}$ & $\begin{array}{l}40.9 \\
40.9\end{array}$ & $\begin{array}{l}\text { methylmalonic aciduria (cobalamin deficiency) cbID } \\
\text { type, with homocystinuria } \\
\text { methylmalonic aciduria (cobalamin deficiency) } \\
\text { cbID type, with homocystinuria }\end{array}$ \\
\hline 6 & $\begin{array}{l}\text { D6Rat143 } \\
(48.1)\end{array}$ & $42-62$ & $\begin{array}{l}0.56 \\
\mathbf{0 . 3 8}\end{array}$ & $\begin{array}{l}\text { XM_576132.1 } \\
\text { XM_001074910.1 }\end{array}$ & $\begin{array}{l}\text { Txndc7 } \\
\text { Oact2 }\end{array}$ & $\begin{array}{l}52.3 \\
60.9\end{array}$ & $\begin{array}{l}\text { Thioredoxin domain containing } 7 \\
\text { O-acyltransferase (membrane bound) domain } \\
\text { containing } 2\end{array}$ \\
\hline 7 & $\begin{array}{l}\text { D7Rat51- } \\
\text { D7Rat165 } \\
(54.6-73.5)\end{array}$ & $44-84$ & 0.57 & XM_235156.4 & Ptprb & 59.4 & $\begin{array}{l}\text { protein tyrosine phosphatase, receptor type, B } \\
\text { (predicted) }\end{array}$ \\
\hline
\end{tabular}

*- the QTL boundaries were determined in the respective one LOD confidence interval. Mb - megabases.

$\triangle$-genes differentially expressed in renal cortex of ISIAH and WAG rats are given in regular type and genes differentially expressed in renal medulla of ISIAH and WAG rats are given in bold type letters.

in QTL and to suggest the candidate genes in the loci for absolute and relative kidney weight which may be related to the structural and mass changes in hypertensive ISIAH kidney.

\section{Genes in QTL for kidney weight}

The QTL for kidney weight in the distal part of Chr.4 in ISIAH rats partially overlaps Kidney mass QTL 34 (Kidm34) (210-233 Mb) found in rats with Metabolic Syndrome $X$ and increased relative kidney weight [24] and with the rat QTL Coreg2 for compensatory renal growth (CRG) (210-224 Mb) of the remnant kidney after unilateral nephrectomy [25]. However, the Cacna1c (216,6 Mb) gene suggested as a positional candidate for CRG in Coreg2 was not significantly expressed (Detection P-value $<0.05$ ) in both kidney cortex and medulla of ISIAH and WAG rats. Two other differentially expressed genes,
Wbp11 and Ptpro, have been located in QTL for kidney weight in ISIAH rats in the distal part of Chr.4 (Figure 3).

Wbp 11 regulates mRNA processing and is involved in RNA splicing [26,27]. Its transcriptional activation is associated with enhanced expression of genes that regulate RNA processing, splicing, and degradation [28]. WBP11 was one of urinary polypeptides significantly down-regulated and specific for essential hypertension with left ventricular diastolic dysfunction that subsequently distinguished hypertensive patients with overt heart failure from healthy controls [29]. The QTL for kidney weight in the distal part of Chr.4 does not overlap with loci for blood pressure traits in ISIAH rats but overlaps with the locus where the ISIAH alleles significantly increase the basal level of corticosterone (Figure 3) [13]. Corticosterone may induce the formation of reactive oxygen species [30] and development of adaptive 


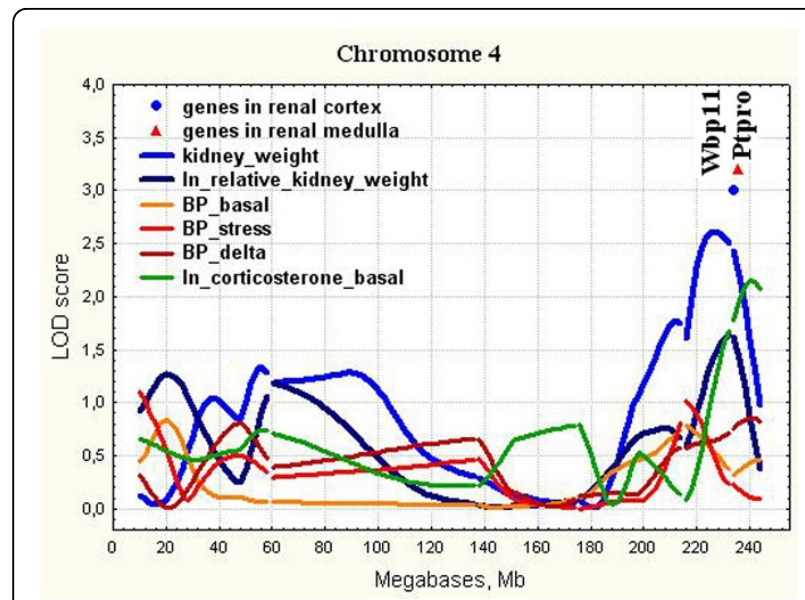

Figure 3 The position of the differentially expressed genes in QTL for kidney weight on chromosome 4. LOD score for kidney weight is 2.61 . It exceeds $1 \%$ chromosome-wise threshold value 2.44

response to oxidative stress may influence the mRNA processing [31] causing both the induction of stressresponse genes and inhibition of gene transcription [32]. So, the down-regulation of Wbp11 in ISIAH kidney may be relevant to changes in transcriptional level of many genes found in current study but probably doesn't have direct effect on the kidney weight or structural changes in kidney histology related to the trait.

Ptpro (or GLEPP1, glomerular epithelial protein 1) is a receptor tyrosine phosphatase expressed on the apical cell surface of the glomerular podocyte [33]. The GLEPP1 (Ptpro) receptor plays a role in regulating the glomerular pressure/filtration rate relationship through an effect on podocyte structure and function. Podocytes

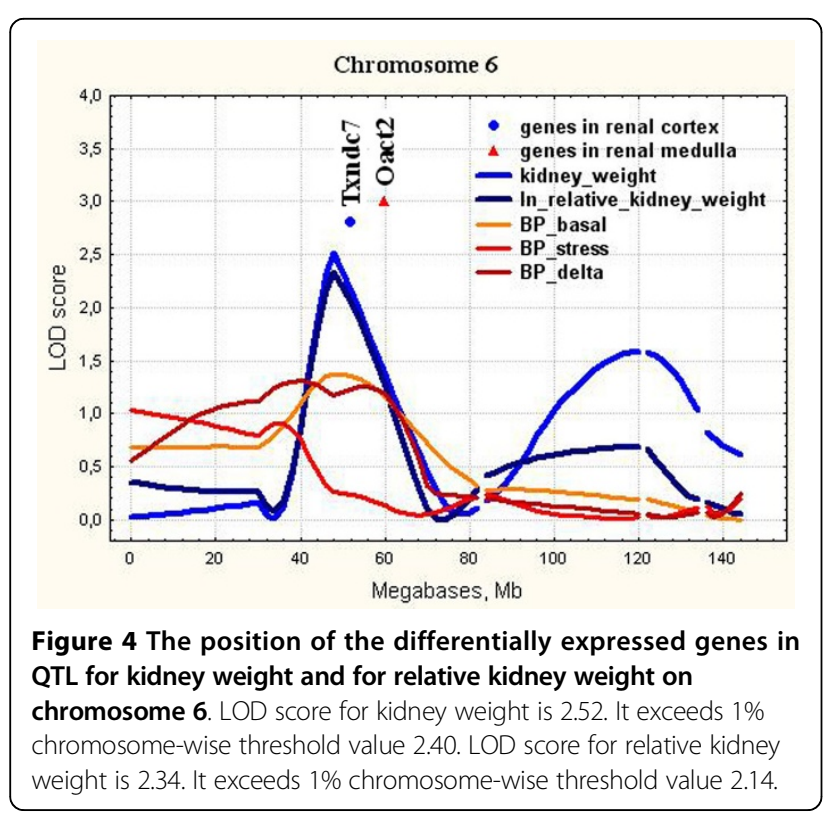

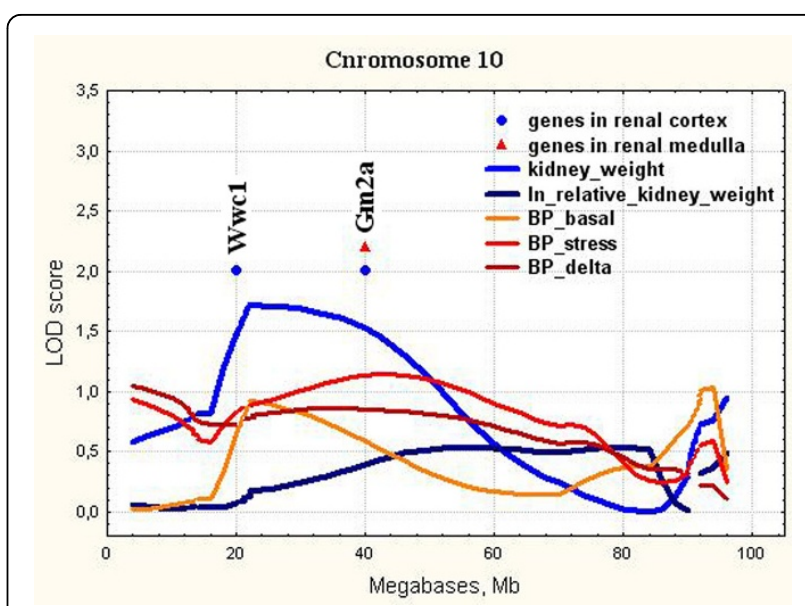

Figure 5 The position of the differentially expressed genes in QTL for kidney weight on chromosome 10. LOD score for kidney weight is 1.72 . It exceeds $5 \%$ chromosome-wise threshold value 1.54 .

are specialized epithelial cells with delicate interdigitating foot processes which cover the exterior basement membrane surface of the glomerular capillary. It was demonstrated that glomerular enlargement is associated with podocyte hypertrophy, podocyte stress, and the decrease in Ptpro expression in the aging Fischer 344 rats known to develop spontaneous glomerulosclerosis with age [34]. Ptpro is localized in QTL for renal function (Rf13) (224-248 Mb) found in hypertensive salt-sensitive rats given a high-salt diet $(8 \% \mathrm{NaCl})$ and associated with change in renal blood flow rate [35]. Ptpro-/- mice had an amoeboid rather than the typical octopoid structure seen in the wild-type mouse podocyte and blunting and widening of the minor (foot) processes. Ptpro ${ }^{-1-}$ mice had reduced glomerular filtration function and a tendency to hypertension [36]. The extensive loss of GLEPP-1 was

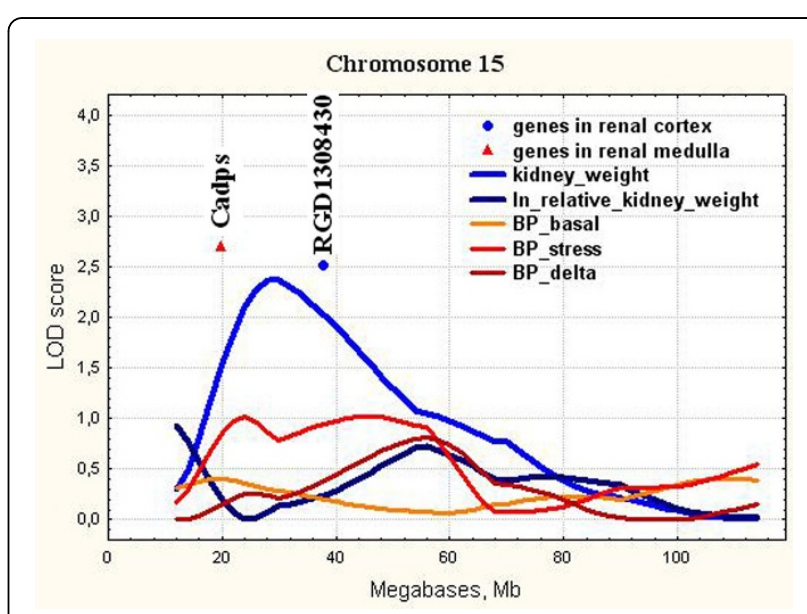

Figure 6 The position of the differentially expressed genes in QTL for kidney weight on chromosome 15 . LOD score for kidney weight is 2.37 . It exceeds $1 \%$ chromosome-wise threshold value 2.12 . 


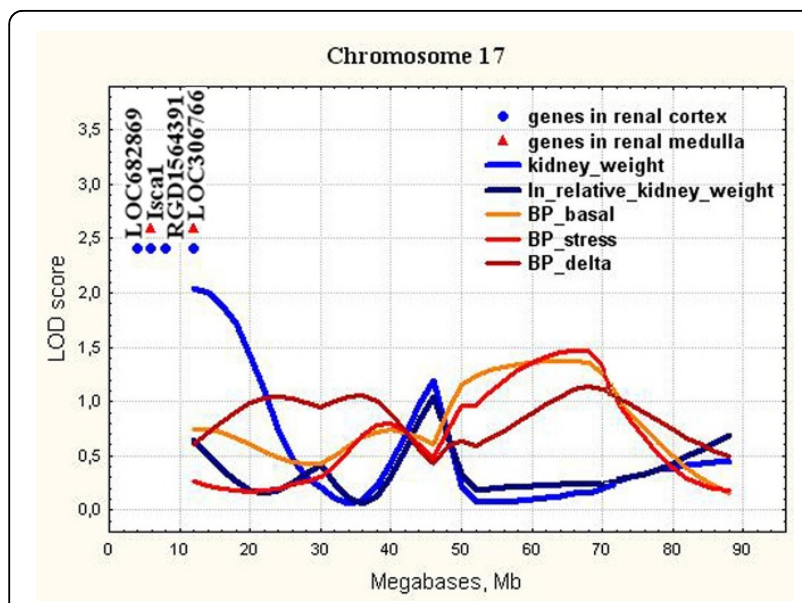

Figure 7 The position of the differentially expressed genes in QTL for kidney weight on chromosome 17. LOD score for kidney weight is 2.04 . It is equal to $2.5 \%$ chromosome-wise threshold value.

found in patients with focal segmental glomerulosclerosis and collapsing glomerulopathy [37]. GLEPP1 expression is considered to be a useful marker of podocyte injury [38]. Ptpro downregulation in ISIAH kidney may be responsible for the podocyte histological changes. It may be considered as a candidate gene for the kidney histological changes leading to the increased kidney weight in ISIAH rats.

Another locus mapped on chromosome 6 was the same for both kidney weight and relative kidney weight traits in ISIAH rats (Figure 4). This locus overlaps with the rat QTL Coreg1 for compensatory renal growth (CRG) (51-70 Mb) of the remnant kidney after unilateral nephrectomy [39]. In our study, the QTL on chromosome 6 contained 2 genes differentially expressed in

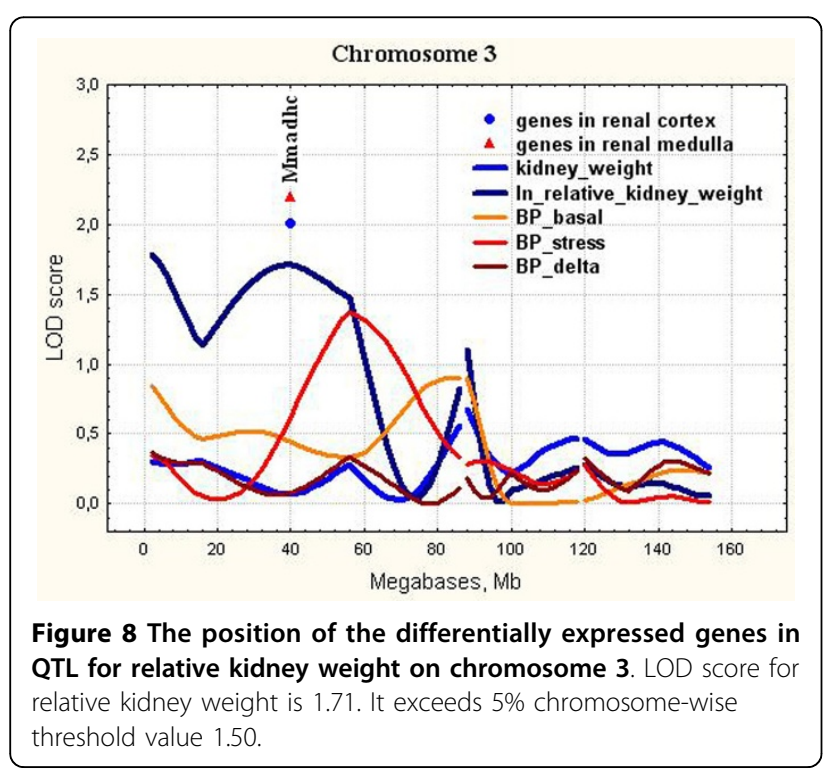

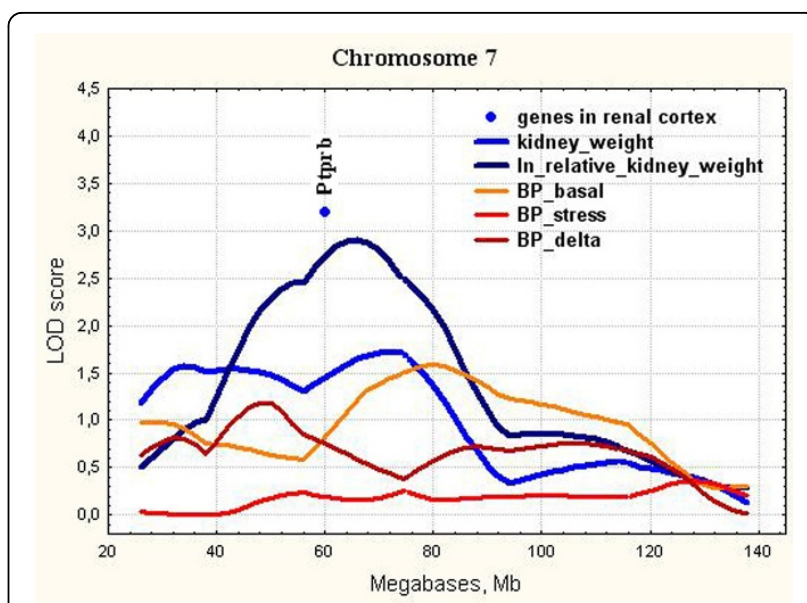

Figure 9 The position of the differentially expressed genes in QTL for relative kidney weight on chromosome 7. LOD score for relative kidney weight is 2.91 . It exceeds $5 \%$ experiment-wise threshold value $=2.74$

hypertensive and normotensive kidney. These were $T x n d c 7$ in renal cortex and Oact2 in renal medulla.

Txndc7 (or Pdia6), is one of the endoplasmic reticulum (ER) resident genes (proteins) that control ER functions and are responsive to cellular stress, including metabolic and oxidative stress. ER stress can be triggered by hypoxia, nutrient deprivation, perturbation of redox status, aberrant $\mathrm{Ca} 2+$ regulation, viral infection, failure of posttranslational modifications, and increased protein synthesis and/or accumulation of unfolded or misfolded proteins in the ER [40]. Gain- and loss-of-function studies showed that PDIA6 protected cardiac myocytes against simulated ischemia/reperfusion-induced death and this protection is dependent on the oxidoreductase activity of PDIA6 [41].

ER stress is a pathologic mechanism in a variety of chronic diseases. ER stress inhibition reduces cardiac damage and improves vascular function in hypertension [42]. The position of Txndc7 corresponds to genome region where small QTL for basal blood pressure may be suggested (Figure 4). According to established statistical approaches this locus for blood pressure can't be considered as significant or even suggestive. The locus is characterized by LOD score 1.37 , and is accounting $4,9 \%$ of the trait variability. From the other side, some researchers agree that many small QTL are smeared across the genome and many small QTL effects control polygenic trait variation [43-45]. Based on this, we may suggest that the decreased expression of the Txndc7 in ISIAH kidney probably doesn't affect the kidney weight but may cause the enhanced cellular ER stress, which may contribute to vascular complications and development of stress-induced hypertension in ISIAH rats.

Oact2 (or Mboat2), O-acyltransferase (membrane bound) domain containing 2 is acyltransferase, which 
mediates the conversion of lysophosphatidylcholine into phosphatidylcholine. Phosphatidylcholine is a major component of cellular membranes and is the most abundant phospholipid in kidney cortical tubules [46]. Its increased biosynthesis was found during renal growth following unilateral nephrectomy [47]. Oact2 was identified as one of the genes with high predictive power $(87 \%)$ in segregating malignant from benign lesions [48]. Oact2 is localized in chromosomal region where the QTL for kidney dilation (Kiddil4) (31.9-94.3 $\mathrm{Mb}$ ) associated with the degree of dilation of the renal pelvis in rats with congenital hydronephrosis [49] and QTL for renal function (Rf14) (44-90 Mb) associated with the salt-loaded renal blood flow [35] were found. The presence of two ISIAH alleles in the QTL for absolute and relative kidney weight on Chr.6 in $\mathrm{F}_{2}$ (ISIAH $\times$ WAG) hybrid males caused the significant decrease in kidney weight and in relative kidney weight [8](Supplement, Table 4). Based on that we may suggest that Oact 2 may be considered as a candidate gene in QTL and its downregulation in ISIAH renal medulla may play protective role against the hyperplastic process in hypertensive kidney.

Wwc1 (Chr.10, Figure 5) encodes KIBRA protein, which is predominantly expressed in the kidney and brain in the adult organism [50]. In the kidney, KIBRA is expressed in glomerular podocytes, in some tubules, and in the collecting duct [51]. KIBRA regulates epithelial cell polarity by suppressing apical exocytosis through direct inhibition of aPKC kinase activity [52]. In renal podocytes, KIBRA/ WWC1 has an impact on targeted cell migration and links polarity complexes to the cytoskeleton [51]. KIBRA regulates precise mitosis [53], cell-cycle progression [54], and it is known as an upstream regulator of tumor suppressor Hippo pathway that regulates cell proliferation and apoptosis [55]. Hippo signaling is an evolutionarily conserved signaling pathway that controls organ size from flies to humans [56]. Hippo-Yap pathway has been shown to play a key role in controlling organ size, primarily by inhibiting cell proliferation and promoting apoptosis. Overexpression and knockdown studies demonstrate that KIBRA promotes the collagen-stimulated activation of the MAPK cascade that is involved in various cellular functions, including cell proliferation, differentiation and migration [57]. KIBRA knockdown impairs cell migration and proliferation in breast cancer cells [58]. Wwc1 is localized in QTL for relative kidney mass (Kidm21) found earlier in the Lyon hypertensive rats [59]. The presence of two ISIAH alleles in the QTL for absolute and relative kidney weight on Chr.10 in $\mathrm{F}_{2}(\mathrm{ISIAH} \times \mathrm{WAG}$ ) hybrid males caused the significant increase in kidney weight [8]. Based on this, we may suggest that $W w c 1$ may be considered as a candidate gene in QTL on Chr.10 for kidney weight and its upregulation in ISIAH renal cortex may play important role in the renal mass gain.

Gm2a (Chr.10, Figure 5) is a lysosomal protein related to lipid transporter activity [60]. It may participate in vesicular transport in collecting duct intercalated cells [61] but nothing is known about its influence on the renal mass.

Cadps (Chr.15, Figure 6) is a Ca++-dependent secretion activator. It is required for optimal vesicle exocytosis in neurons and endocrine cells [62]. It regulates catecholamine release from neuroendocrine cells through the interaction with dopamine D2 receptor [63]. The deletion of CADPS alleles causes the deficit in catecholamine secretion [64]. Dopamine receptors of DA-2 subtypes are localized in sympathetic nerve terminals innervating the renal blood vessels. Some selective DA-2 receptor agonists are effective antihypertensive agents [65]. CADPS is one of the positional candidate genes in human blood pressure quantitative trait loci [66]. Genetic down-regulation of genes related to the adrenergic system (including Cadps) might play a role in splanchnic vasodilation of portal hypertension [67]. Cadps location corresponds to chromosomal region characterized by a very low LOD score 1.01 for blood pressure level at stress in ISIAH rats (Figure 6). But, as we agree that many small QTL effects control polygenic trait variation, we suggest that $C a d p s$ downregulation may be a part of adaptive mechanism against BP elevation at stress in ISIAH rats.

Isca1 (Chr.17, Figure 7) is implicated in the biogenesis of iron-sulfur clusters. Iron-sulfur clusters are integral parts of proteins that participate in oxidation-reduction reactions and catalysis $[68,69]$. It is known, that iron is essential for healthy life and is involved in numerous metabolic processes including cell growth and proliferation [70]. However, no relations between Iscal and kidney weight were reported.

Several other genes with differential expression and unknown functions were also detected in the QTL for kidney weight on Chr.15 and Chr.17 (Figures 6 - 7). The further studies are needed to define their functions which probably may be related to increased kidney weight and structure abnormalities in ISIAH rats.

\section{Genes in QTL for relative kidney weight}

In the current study, the QTL for relative kidney weight on Chr. 3 contained the only differentially expressed gene (Figure 8). It was Mmadhc gene. Its expression was significantly decreased in hypertensive ISIAH kidney.

Mmadhc is related to cobalamin (Cbl, vitamin B12) transport and metabolism, the defects of which may cause methylmalonic aciduria, homocystinuria, or both $[71,72]$. Patients with methylmalonic aciduria often 
develop chronic renal failure (CRF) [73]. Kidney weight per unit of body weight was significantly greater in the Cbl-deficient rats compared with the two Cbl-sufficient control groups [74]. Mmadhc is localized in chromosomal region where the QTL for kidney mass (Kidm13) was found in the Lyon hypertensive rats [59]. The presence of two ISIAH alleles in the QTL for relative kidney weight on Chr.3 in $\mathrm{F}_{2}($ ISIAH $\times$ WAG) hybrid males caused the significant increase in relative kidney weight [8](Supplement, Table 4). We suggest that decrease in Mmadhc expression may contribute to the increase in relative kidney weight in ISIAH rats due to a possible abnormal cobalamin transport and metabolism.

The chromosome 6 was characterized by QTL common for absolute and relative kidney weight (Figure 4). The genes differentially expressed in ISIAH and WAG kidney and located in QTL on Chr.6 were discussed above.

Ptprb (Chr.7, Figure 9) is a receptor protein tyrosine phosphatase beta. It is a receptor for heparin affin regulatory peptide (HARP), which is a growth factor that has a potent role in tumor growth and angiogenesis. RPTP $\beta$ down-regulation interrupts HARP signaling in human umbilical vein endothelial cells and abolishes its biological activity on cell migration and differentiation [75]. Ptprb expression mediates deafferentation-induced synaptogenesis [76] and regulates sodium channel modulation in brain neurons [77].

The earlier studies have demonstrated adrenergic nerve terminals in direct contact with basal membranes of mammalian renal tubular epithelial cells. The stimulation of renal sympathetic nerves produces an increase in renal tubular sodium reabsorption without alterations in glomerular filtration rate, renal blood flow, or intrarenal distribution of blood flow [78]. As soon as the statistically significant plasma sodium increase was found in ISIAH rats as compared to normotensive WAG [79], we may suggest that the decreased expression of Ptprb in ISIAH kidney may be adaptive against the excessive renal sodium retention but probably doesn't influence the kidney weight.

In the current study, we showed that all loci found for absolute and relative kidney weight didn't overlap with significant or suggestive loci for BP traits (Figure 3, 4, 5, $6,7,8,9)$. So, the genes differentially expressed in ISIAH and WAG kidneys and located in these QTL regions associated with absolute and relative kidney weight shouldn't substantially influence the BP level in the 6 month-old ISIAH rats. However, we consider that in some cases small effects may be suggested and that is in a good agreement with the recent insights into genetic architecture of complex diseases [80]. These loci, one by one, have a little association with the blood pressure. However, one can expect that the summation of their effects in a whole genome can result in much more higher levels of the association.

Earlier we described several loci common for relative kidney weight and blood pressure traits in QTL analysis of $\mathrm{F}_{2}(\mathrm{ISIAH} \times \mathrm{WAG})$ hybrid males aged 3-4 month old [8]. We suggested the important role of kidney function in early stage of hypertension manifestation in ISIAH rats and switching to other mechanisms leading to genetic control of BP level in the 6-month-old rats. It was shown that the significant QTL on chromosome 1 was common for arterial blood pressure at rest and under the emotional stress conditions and for relative spleen weight in the 6-month-old $\mathrm{F}_{2}$ (ISIAHxWAG) rats. These results suggest that the manifestation of the stress-sensitive arterial hypertension in ISIAH rats of that age may be under the genetic control of the determinants related to the spleen function [81]. This dynamic change of QTL effects during a time course might reflect the process of stress-sensitive hypertension development.

Earlier some authors reported that a phenotype having some genetic component may be affected by different genetic loci at different age. It was considered highly plausible and was shown in different organisms: rats [82,83], chicken [84], humans [85]. The dynamic change of QTL effects during the time course of growth points out that early and late growth, at least to some extent, have different genetic regulation [84].

The distinct kidney mass QTLs independent of those controlling BP were found earlier in studies of different models of hypertensive rats $[2,86]$. These and our studies suggest that kidney mass can be controlled by physiologic mechanisms different from those responsible for BP. As soon as the kidney mass has been viewed as a significant risk factor for the progression of renal diseases [87] the discovery of individual kidney mass QTLs may help to identify the mechanisms underlying renal hypertrophy independent of hypertension.

\section{Conclusion}

The differentially expressed genes found in QTL may relate not only to the traits under study, but to other interstrain differences as well. However, the QTL/microarray approach and the knowledge-driven filtering of the list of candidates helped to determine several positional candidate genes in the QTL for absolute and relative kidney weight, which may be related to the structural and mass changes in hypertensive ISIAH kidney. These were Mmadhc, Ptpro, Oact2 and Wwc1.

The rationale behind QTL/microarray studies is that causative genes may have polymorphisms causing differences in their level of expression that translate into varying amounts of mRNA and ultimately varying amounts of functional proteins, leading to observable 
phenotypes [88]. From the other side the differential transcription of the QTL-associated candidate genes may be a result of the trans-regulation mechanism.

The further experimental validation of causative genes and detection of polymorphisms will provide opportunities to significantly advance our understanding of the underlying nature of structural and mass changes in hypertensive ISIAH kidney.

\section{Competing interests}

The authors report no conflicts of interest. The authors alone are responsible for the content and writing of the paper.

\section{Authors' contributions}

OR carried out the QTL analysis, performed the statistical analysis and drafted the manuscript. SS carried out the QTL analysis, participated in the statistical analysis and drafted the manuscript. LK performed hierarchical cluster analyses and heatmaps construction. AM conceived of the study, participated in its design and coordination and helped to draft the manuscript.

\section{Acknowledgements}

The authors are grateful to JSC Genoanalytica (Moscow, Russia) for conducting the array hybridization experiment and the primary statistical analysis of the hybridization results. This work has been supported by the Russian Science Foundation. The study was conducted in the Center for Genetic Resources of Laboratory Animals at the Institute of Cytology and Genetics SB RAS (RFMEF161914X0005). Computer calculations were supported by SSCC SB RAS.

\section{Declarations}

Publication of this article has been funded by the RSF 14-14-00269 grant This article has been published as part of BMC Genetics Volume 16 Supplement 1, 2015: Selected articles from the IX International Conference on the Bioinformatics of Genome Regulation and StructurelSystems Biology (BGRSISB-2014): Genetics. The full contents of the supplement are available online at http://www.biomedcentral.com/bmcgenet/supplements/16/S1.

\section{Authors' details}

'Institute of Cytology and Genetics, Siberian Branch of Russian Academy of Sciences, Novosibirsk, 630090 Russia. ${ }^{2}$ Novosibirsk State University, Novosibirsk, 630090 Russia.

Published: 2 February 2015

\section{References}

1. Mullins $\sqcup$, Bailey MA, Mullins JJ: Hypertension, kidney, and transgenics: a fresh perspective. Physiol Rev 2006, 86:709-46.

2. Hamet P, Pausova Z, Dumas P, Sun YL, Tremblay J, Pravenec M, Kunes J, Krenova D, Kren V: Newborn and adult recombinant inbred strains: a tool to search for genetic determinants of target organ damage in hypertension. Kidney Int 1998, 53:1488-92

3. Pravenec M, Kren V, Krenova D, Zidek V, Simakova M, Musilova A, Vorlicek J, Lezin ES, Kurtz TW: Genetic isolation of quantitative trait loci for blood pressure development and renal mass on chromosome 5 in the spontaneously hypertensive rat. Physiol Res 2003, 52:285-9.

4. Dornas WC, Silva ME: Animal models for the study of arterial hypertension. J Biosci 2011, 36:731-7.

5. Markel AL: Development of a new strain of rats with inherited stressinduced arterial hypertension. In Genetic hypertension. Volume 218. London: Colloque INSERM;Sassard J 1992:405-407.

6. Markel AL, Maslova LN, Shishkina GT, Bulygina W, Machanova NA, Jacobson GS: Developmental influences on blood pressure regulation in ISIAH rats. In Development of the hypertensive phenotype: basic and clinical studies. Volume 19. Amsterdam-Lausanne-NewYork-OxfordShannon-Singapore-Tokyo: Elsevier;McCarty R, Blizard DA, Chevalier RL 1999:493-526.
7. Redina OE, Machanova NA, Efimov VM, Markel AL: Rats with inherited stress-induced arterial hypertension (ISIAH strain) display specific quantitative trait loci for blood pressure and for body and kidney weight on chromosome 1. Clin Exp Pharmacol Physiol 2006, 33:456-64.

8. Redina OE, Smolenskaya SE, Maslova LN, Markel AL: The genetic control of blood pressure and body composition in rats with stress-sensitive hypertension. Clin Exp Hypertens 2013, 35:484-95.

9. Pomp D, Allan MF, Wesolowski SR: Quantitative genomics: exploring the genetic architecture of complex trait predisposition. J Anim Sci 2004, 82(E-Suppl):E300-312.

10. Kwitek-Black AE, Jacob HJ: The use of designer rats in the genetic dissection of hypertension. Curr Hypertens Rep 2001, 3:12-18.

11. Drake TA, Schadt EE, Lusis AJ: Integrating genetic and gene expression data: application to cardiovascular and metabolic traits in mice. Mamm Genome 2006, 17:466-79.

12. Redina OE, Smolenskaya SE, Abramova TO, Ivanova LN, Markel AL: Differential transcriptional activity of kidney genes in hypertensive ISIAH and normotensive WAG rats. Clinical and Experimental Hypertension 2014, DOI: 10.3109/10641963.2014.954711

13. Redina OE, Smolenskaya SE, Maslova LN, Markel AL: Genetic Control of the Corticosterone Level at Rest and Under Emotional Stress in ISIAH Rats with Inherited Stress-Induced Arterial Hypertension. Clin Exp Hypertens 2010, 32:364-71.

14. Lander ES, Green P, Abrahamson J, Barlow A, Daly MJ, Lincoln SE, Newburg L: MAPMAKER: an interactive computer package for constructing primary genetic linkage maps of experimental and natural populations. Genomics 1987, 1:174-81.

15. Basten CJ, Weir BS, Zeng Z-B: Zmap-a QTL cartographer. In Proceedings of the 5th World Congress on Genetics Applied to Livestock Production: Computing Strategies and Software. Volume 22. Guelph, Ontario, Canada: Organizing Committee, 5th World Congress on Genetics Applied to Livestock Production;Smith C, Gavora JS, Benkel B, Chesnais J, Fairfull W, Gibson JP, Kennedy BW, Burnside EB 1994:65-66.

16. Basten CJ, Weir BS, Zeng Z-B: QTL Cartographer, Version 1.17. Department of Statistics, North Carolina State University, Raleigh, NC; 2004.

17. Churchill GA, Doerge RW: Empirical Threshold Values for Quantitative Trait Mapping. Genetics 1994, 138:963-971.

18. Lander $E$, Kruglyak L: Genetic dissection of complex traits: guidelines for interpreting and reporting linkage results. Nat Genet 1995, 11:241-7.

19. Fine L: The biology of renal hypertrophy. Kidney Int 1986, 29:619-34.

20. Nyengaard JR, Bendtsen TF: Glomerular number and size in relation to age, kidney weight, and body surface in normal man. Anat Rec 1992, 232:194-201.

21. Shmerling MD, Filiushina EE, Lazarev VA, Buzueva II, Markel' AL, lakobson GS: Ultrastructural changes of kidney corpuscles in rats with hereditary stress-induced arterial hypertension [Article in Russian]. Morfologiia 2001, 120:70-74.

22. Filyushina EE, Shmerling MD, Buzueva II, Lazarev VA, Markel AL, Yakobson GS: Structural characteristics of renomedullary interstitial cells of hypertensive ISIAH rats. Bull Exp Biol Med 2013, 155:408-12.

23. Hoffman P, Tabakoff B: Gene expression in animals with different acute responses to ethanol. Addict Biol 2005, 10:63-9.

24. Seda O, Liska F, Krenova D, Kazdova L, Sedova L, Zima T, Peng J, Pelinkova K, Tremblay J, Hamet P, et al: Dynamic genetic architecture of metabolic syndrome attributes in the rat. Physiol Genomics 2005, 21:243-52.

25. Pravenec M, Zidek V, Musilova A, Kren V, Bila V, Di Nicolantonio R: Chromosomal mapping of a major quantitative trait locus regulating compensatory renal growth in the rat. J Am Soc Nephrol 2000, 11:1261-5.

26. Komuro A, Saeki M, Kato S: Npw38, a novel nuclear protein possessing a WW domain capable of activating basal transcription. Nucleic Acids Res 1999, 27:1957-65.

27. Llorian M, Beullens M, Andre's I, Ortiz JM, Bollen M: SIPP1, a novel premRNA splicing factor and interactor of protein phosphatase-1. Biochem J 2004, 378:229-38.

28. Fathallah-Shaykh HM, He B, Zhao LJ, Engelhard HH, Cerullo L, Lichtor T, Byrne R, Munoz L, Von Roenn K, Rosseau GL, et al: Genomic expression discovery predicts pathways and opposing functions behind phenotypes. J Biol Chem 2003, 278:23830-3.

29. Kuznetsova T, Mischak H, Mullen W, Staessen JA: Urinary proteome analysis in hypertensive patients with left ventricular diastolic dysfunction. Eur Heart J 2012, 33:2342-50. 
30. Lin H, Decuypere E, Buyse J: Oxidative stress induced by corticosterone administration in broiler chickens (Gallus gallus domesticus) 1. Chronic exposure. Comp Biochem Physiol B Biochem Mol Biol 2004, 139:737-44.

31. de Nadal E, Ammerer G, Posas F: Controlling gene expression in response to stress. Nat Rev Genet 2011, 12:833-45.

32. Morel $Y$, Barouki R: Repression of gene expression by oxidative stress. Biochem J 1999, 342:481-96.

33. Thomas PE, Wharram BL, Goyal M, Wiggins JE, Holzman LB, Wiggins RC: GLEPP1, a renal glomerular epithelial cell (podocyte) membrane proteintyrosine phosphatase. Identification, molecular cloning, and characterization in rabbit. J Biol Chem 1994, 269:19953-62.

34. Wiggins JE, Goyal M, Sanden SK, Wharram BL, Shedden KA, Misek DE, Kuick RD, Wiggins RC: Podocyte hypertrophy, "adaptation," and "decompensation" associated with glomerular enlargement and glomerulosclerosis in the aging rat: prevention by calorie restriction. J Am Soc Nephrol 2005, 16:2953-66.

35. Moreno C, Dumas P, Kaldunski ML, Tonellato PJ, Greene AS, Roman RJ, Cheng Q, Wang Z, Jacob HJ, Cowley AWJ: Genomic map of cardiovascular phenotypes of hypertension in female Dahl S rats. Physiol Genomics 2003, 15:243-57.

36. Wharram BL, Goyal M, Gillespie PJ, Wiggins JE, Kershaw DB, Holzman LB, Dysko RC, Saunders TL, Samuelson LC, Wiggins RC: Altered podocyte structure in GLEPP1 (Ptpro)-deficient mice associated with hypertension and low glomerular filtration rate. J Clin Invest 2000, 106:1281-90.

37. Barisoni L, Kriz W, Mundel P, D'Agati V: The dysregulated podocyte phenotype: a novel concept in the pathogenesis of collapsing idiopathic focal segmental glomerulosclerosis and HIV-associated nephropathy. J Am Soc Nephrol 1999, 10:51-61.

38. Kim YH, Goyal M, Wharram B, Wiggins J, Kershaw D, Wiggins R: GLEPP1 receptor tyrosine phosphatase (Ptpro) in rat PAN nephrosis. A marker of acute podocyte injury. Nephron 2002, 90:471-6.

39. Pravenec M, Zidek V, Simakova M, Vorlicek J, Kren V: Linkage mapping of the Fos cellular oncogene (Fos) to rat chromosome 6 and its possible role in the regulation of compensatory renal growth. Folia Biol (Praha) 1998, 44:151-3.

40. Mei $Y$, Thompson MD, Cohen RA, Tong X: Endoplasmic Reticulum Stress and Related Pathological Processes. J Pharmacol Biomed Anal 2013, 1:1000107.

41. Vekich JA, Belmont PJ, Thuerauf DJ, Glembotski CC: Protein disulfide isomerase-associated 6 is an ATF6-inducible ER stress response protein that protects cardiac myocytes from ischemia/reperfusion-mediated cell death. J Mol Cell Cardiol 2012, 53:259-67.

42. Kassan M, Gala'n M, Partyka M, Saifudeen Z, Henrion D, Trebak M, Matrougui $\mathrm{K}$ : Endoplasmic reticulum stress is involved in cardiac damage and vascular endothelial dysfunction in hypertensive mice. Arterioscler Thromb Vasc Biol 2012, 32:1652-61.

43. Meuwissen TH, Hayes BJ, Goddard ME: Prediction of total genetic value using genome-wide dense marker maps. Genetics 2001, 157:1819-29.

44. Meuwissen TH: Accuracy of breeding values of 'unrelated' individuals predicted by dense SNP genotyping. Genet Sel Evol 2009, 41:35.

45. Clark SA, Hickey JM, van der Werf JH: Different models of genetic variation and their effect on genomic evaluation. Genet Sel Evol 2011, 43:18.

46. Wirthensohn G, Lefrank S, Wirthensohn K, Guder WG: Phospholipid metabolism in rat kidney cortical tubules. I. Effect of renal substrates. Biochim Biophys Acta 1984, 795:392-400.

47. Hise MK, Harris RH, Mansbach CMn: Regulation of de novo phosphatidylcholine biosynthesis during renal growth. Am J Physiol 1984, 247:F260-6.

48. Basil CF, Zhao Y, Zavaglia K, Jin P, Panelli MC, Voiculescu S, Mandruzzato S, Lee HM, Seliger B, Freedman RS, et al: Common cancer biomarkers. Cancer Res 2006, 66:2953-61

49. Kota L, Schulz H, Falak S, Hu"bner N, Osborne-Pellegrin M: Localization of genetic loci controlling hydronephrosis in the Brown Norway rat and its association with hematuria. Physiol Genomics 2008, 34:215-24.

50. Schneider A, Huentelman MJ, Kremerskothen J, Duning K, Spoelgen R, Nikolich K: KIBRA: A New Gateway to Learning and Memory? Front Aging Neurosci 2010, 2:4

51. Duning K, Schurek EM, Schluter M, Bayer M, Reinhardt HC, Schwab A, Schaefer L, Benzing T, Schermer B, Saleem MA, et al: KIBRA modulates directional migration of podocytes. J Am Soc Nephrol 2008, 19:1891-903.
52. Yoshihama Y, Sasaki K, Horikoshi Y, Suzuki A, Ohtsuka T, Hakuno F, Takahashi S, Ohno S, Chida K: KIBRA suppresses apical exocytosis through inhibition of aPKC kinase activity in epithelial cells. Curr Biol 2011, 21:705-11.

53. Zhang L, lyer J, Chowdhury A, Ji M, Xiao L, Yang S, Chen Y, Tsai MY, Dong J: KIBRA regulates aurora kinase activity and is required for precise chromosome alignment during mitosis. J Biol Chem 2012, 287:34069-77.

54. Ji M, Yang S, Chen Y, Xiao L, Zhang L, Dong J: Phospho-regulation of KIBRA by CDK1 and CDC14 phosphatase controls cell-cycle progression. Biochem J 2012, 447:93-102.

55. Yoshihama $Y$, Izumisawa $Y$, Akimoto $K$, Satoh $Y$, Mizushima T, Satoh K, Chida K, Takagawa R, Akiyama H, Ichikawa $Y$, et al: High expression of KIBRA in low atypical protein kinase C-expressing gastric cancer correlates with lymphatic invasion and poor prognosis. Cancer Sci 2013 104:259-65.

56. Pan D: Hippo signaling in organ size control. Genes Dev 2007, 21:886-97.

57. Hilton HN, Stanford PM, Harris J, Oakes SR, Kaplan W, Daly RJ, Ormandy CJ: KIBRA interacts with discoidin domain receptor 1 to modulate collageninduced signalling. Biochim Biophys Acta 2008, 1783:383-93.

58. Yang S, Ji M, Zhang L, Chen Y, Wennmann DO, Kremerskothen J, Dong J: Phosphorylation of KIBRA by the extracellular signal-regulated kinase (ERK)-ribosomal S6 kinase (RSK) cascade modulates cell proliferation and migration. Cell Signal 2014, 26:343-51.

59. Bilusic M, Bataillard A, Tschannen MR, Gao L, Barreto NE, Vincent M, Wang T, Jacob HJ, Sassard J, Kwitek AE: Mapping the genetic determinants of hypertension, metabolic diseases, and related phenotypes in the lyon hypertensive rat. Hypertension 2004, 44:695-701.

60. Kuwana T, Mullock BM, Luzio JP: Identification of a lysosomal protein causing lipid transfer, using a fluorescence assay designed to monitor membrane fusion between rat liver endosomes and lysosomes. Biochem J 1995, 308:937-46.

61. Mundel TM, Heid HW, Mahuran DJ, Kriz W, Mundel P: Ganglioside GM2activator protein and vesicular transport in collecting duct intercalated cells. J Am Soc Nephrol 1999, 10:435-43.

62. Daily NJ, Boswell K, James DJ, Martin TF: Novel interactions of CAPS (Ca2 +-dependent activator protein for secretion) with the three neuronal SNARE proteins required for vesicle fusion. J Biol Chem 2010, 285:35320-9.

63. Binda AV, Kabbani N, Levenson R: Regulation of dense core vesicle release from PC12 cells by interaction between the D2 dopamine receptor and calcium-dependent activator protein for secretion (CAPS). Biochem Pharmacol 2005, 69:1451-61.

64. Liu Y, Schirra C, Stevens DR, Matti U, Speidel D, Hof D, Bruns D, Brose N, Rettig J: CAPS facilitates filling of the rapidly releasable pool of large dense-core vesicles. J Neurosci 2008, 28:5594-601.

65. Lokhandwala MF, Amenta F: Anatomical distribution and function of dopamine receptors in the kidney. FASEB J 1991, 5:3023-30.

66. Tomaszewski M, Padmanabhan S, Miller WH, Lee WK, Dominiczak AF: Genetic factors. In Manual of Hypertension of the European Society of Hypertension. Volume Part 2. United Kingdom: Informa Healthcare;Mancia G, Grassi G, Kjeldsen SE 2008:84-93.

67. Coll M, Genesca J, Raurell I, Rodri'guez-Vilarrupla A, Meji'as M, Otero T, Oria M, Esteban R, Guardia J, Bosch J, et al: Down-regulation of genes related to the adrenergic system may contribute to splanchnic vasodilation in rat portal hypertension. J Hepatol 2008, 49:43-51.

68. Rouault TA, Klausner RD: Iron-sulfur clusters as biosensors of oxidants and iron. Trends Biochem Sci 1996, 21:174-7.

69. Wang J, Pantopoulos K: Regulation of cellular iron metabolism. Biochem J 2011, 434:365-81.

70. Xiong W, Wang L, Yu F: Regulation of cellular iron metabolism and its implications in lung cancer progression. Med Oncol 2014, 31:28.

71. Coelho D, Suormala T, Stucki M, Lerner-Ellis JP, Rosenblatt DS, Newbold RF, Baumgartner MR, Fowler B: Gene identification for the cbID defect of vitamin B12 metabolism. N Engl J Med 2008, 358:1454-64.

72. Mah W, Deme JC, Watkins D, Fung S, Janer A, Shoubridge EA, Rosenblatt DS, Coulton JW: Subcellular location of MMACHC and MMADHC, two human proteins central to intracellular vitamin $B(12)$ metabolism. Mol Genet Metab 2013, 108:112-8.

73. Morath MA, Okun JG, Muller IB, Sauer SW, Horster F, Hoffmann GF, Kolker S: Neurodegeneration and chronic renal failure in methylmalonic aciduria-a pathophysiological approach. J Inherit Metab Dis 2008, 31:35-43. 
74. Nakao M, Kono N, Adachi S, Ebara S, Adachi T, Miura T, Yamaji R, Inui H, Nakano Y: Abnormal increase in the expression level of proliferating cell nuclear antigen (PCNA) in the liver and hepatic injury in rats with dietary cobalamin deficiency. J Nutr Sci Vitaminol (Tokyo) 2006, 52:168-73.

75. Polykratis A, Katsoris P, Courty J, Papadimitriou E: Characterization of heparin affin regulatory peptide signaling in human endothelial cells. J Biol Chem 2005, 280:22454-61.

76. Harris $J$, Reeves TM, Phillips LL: Phosphacan and receptor protein tyrosine phosphatase beta expression mediates deafferentation-induced synaptogenesis. Hippocampus 2011, 21:81-92.

77. Ratcliffe CF, Qu Y, McCormick KA, Tibbs VC, Dixon JE, Scheuer T, Catterall WA: A sodium channel signaling complex: modulation by associated receptor protein tyrosine phosphatase beta. Nat Neurosci 2000, 3:437-44.

78. DiBona GF, Zambraski EJ, Aguilera AJ, Kaloyanides GJ: Neurogenic control of renal tubular sodium reabsorption in the dog: a brief review and preliminary report concerning possible humoral mediation. Circ Res 1977, 40:1127-30.

79. Fedoseeva LA, Riazanova MA, Antonov EV, Dymshits GM, Markel' AL: Reninangiotensin system gene expression in the kidney and in the heart in hypertensive ISIAH rats. [Article in Russian]. Biomed Khim 2011, 57:410-9.

80. Manolio TA, Collins FS, Cox NJ, Goldstein DB, Hindorff LA, Hunter DJ, McCarthy MI, Ramos EM, Cardon LR, Chakravarti A, et al: Finding the missing heritability of complex diseases. Nature 2009, 461:747-53.

81. Redina OE, Smolenskaya SE, Abramova TO, Markel AL: Genetic Loci for Spleen Weight and Blood Pressure in ISIAH Rats with Inherited StressInduced Arterial Hypertension. Molecular Biology 2014, 48:351-358.

82. Samani NJ, Gauguier D, Vincent M, Kaiser MA, Bihoreau MT, Lodwick D, Wallis R, Parent V, Kimber $P$, Rattray $F$, et al: Analysis of quantitative trait loci for blood pressure on rat chromosomes 2 and 13. Age-related differences in effect. Hypertension 1996, 28:1118-22.

83. Garrett MR, Dene H, Rapp JP: Time-course genetic analysis of albuminuria in Dahl salt-sensitive rats on low-salt diet. J Am Soc Nephrol 2003, 14:1175-87.

84. Carlborg O, Kerje S, Schu"tz K, Jacobsson L, Jensen P, Andersson L: A global search reveals epistatic interaction between QTL for early growth in the chicken. Genome Res 2003, 13:413-21.

85. Beck SR, Brown WM, Williams AH, Pierce J, Rich SS, Langefeld CD: Agestratified QTL genome scan analyses for anthropometric measures. BMC Genet 2003, 4:S31.

86. Duong C, Charron S, Xiao C, Hamet P, Me'nard A, Roy J, Deng AY: Distinct quantitative trait loci for kidney, cardiac, and aortic mass dissociated from and associated with blood pressure in Dahl congenic rats. Mamm Genome 2006, 17:1147-61.

87. Brenner BM, Mackenzie HS: Nephron mass as a risk factor for progression of renal disease. Kidney Int Suppl 1997, 63:S124-7.

88. Verdugo RA, Farber $\mathrm{CR}$, Warden $\mathrm{CH}$, Medrano JF: Serious limitations of the QTL/microarray approach for QTL gene discovery. BMC Biol 2010, 8:96

doi:10.1186/1471-2156-16-S1-S1

Cite this article as: Redina et al:: Candidate genes in quantitative trait loci associated with absolute and relative kidney weight in rats with Inherited Stress Induced Arterial Hypertension. BMC Genetics 2015 16(Suppl 1):S1.

\section{Submit your next manuscript to BioMed Central and take full advantage of:}

- Convenient online submission

- Thorough peer review

- No space constraints or color figure charges

- Immediate publication on acceptance

- Inclusion in PubMed, CAS, Scopus and Google Scholar

- Research which is freely available for redistribution

Submit your manuscript at www.biomedcentral.com/submit
Ciomed Central 